\title{
Celiac disease in children and adolescents with Down syndrome
}

\author{
Doença celíaca em crianças e adolescentes com síndrome de Down
}

\author{
Renato M. Nisihara, ${ }^{1}$ Lorete M. S. Kotze, ${ }^{2}$ Shirley R. R. Utiyama, ${ }^{3}$ Nanci P. Oliveira, ${ }^{4}$ \\ Patrícia T. Fiedler, ${ }^{4}$ Iara T. Messias-Reason ${ }^{3}$
}

\begin{abstract}
Objectives: High prevalence rates of celiac disease in patients with Down syndrome have been reported in several countries. However, in Brazil there are no data regarding this association. In this study we report the prevalence of celiac disease in Down syndrome children and adolescents from southern Brazil.

Methods: Seventy-one patients (32 female and 39 male, 2-18 years) from Curitiba, Brazil, were studied. Eighty young people (42 male and 38 female, 2-19 years) were used as controls. All subjects were screened for the IgA-antiendomysium antibody $(\mathrm{EmA})$ and IgA anti-tecidual transglutaminase (anti-tTG). EmA was measured by an immunofluorescence assay using umbilical cord as the substrate and anti-tTG by ELISA with tecidual transglutaminase as the antigen. The total IgA serum level was determined by turbidimetry.

Results: Five DS patients ( $7 \%$ ) were positive for EmA-IgA, with titers from $1 / 5$ to $1 / 80$ and 14 (17.5\%) for anti-tTG (21-340 units). All EmA positive patients also presented anti-tTG antibodies simultaneously. Clinical and histological findings of the intestinal mucosa confirmed celiac disease diagnoses in four patients. The other EmA positive patient was asymptomatic and was not submitted to duodenal biopsy. Patients only positive for anti-tTG presented borderline values ( $<25$ units) and were asymptomatic. None of the controls were positive for EmA or anti-tTG. No Down syndrome patients or controls presented IgA deficiency.
\end{abstract}

Conclusions: These data indicate a high prevalence $(5.6 \%)$ of confirmed celiac disease in Down syndrome patients from southern Brazil.

J Pediatr (Rio J). 2005; 81(5):373-6: Antiendomisyum antibodies, anti-transglutaminase antibodies, celiac disease, Down syndrome.

1. MSc. Laboratory of Immunopathology, Hospital das Clínicas, Universidade Federal do Paraná (UFPR), Curitiba, PR.

2. MD. Service of Gastroenterology and Digestive Endoscopy, Hospital Universitário Cajuru, Pontifícia Universidade Católica do Paraná (PUCPR), Curitiba, PR.

3. PhD. Laboratory of Immunopathology, Hospital das Clínicas, UFPR, Curitiba, PR.

4. MD. Down Syndrome Clinic, Hospital das Clínicas, UFPR, Curitiba, PR. Manuscript received Sep 21 2004, accepted for publication Apr 132005.

Suggested citation: Nisihara RM, Kotze LM, Utiyama SR, Oliveira NP, Fiedler PT, Messias-Reason IT. Celiac disease in children and adolescents with Down syndrome. J. Pediatr (Rio J). 2005;81:373-6.

\section{Resumo}

Objetivos: Alta prevalência de doença celíaca em pacientes com síndrome de Down tem sido descrita em vários países. No entanto, no Brasil ainda não há relatos mostrando essa associação. $O$ presente estudo teve como objetivo avaliar a prevalência de doença celíaca em crianças e adolescentes com síndrome de Down no sul do Brasil.

Métodos: Setenta e um pacientes (32 do sexo feminino e 39 masculino, 2-18 anos) provenientes de Curitiba, Brasil, foram estudados. Oitenta indivíduos (42 do sexo masculino e 38 feminino, 2-19 anos) foram utilizados como controles do estudo. Todas as amostras foram investigadas para anticorpo anti-endomísio (EmA) e anti-transglutaminase tecidual (anti-tTG). O EmA foi pesquisado através de imunofluorescência indireta usando cordão umbilical como substrato e o anti-tTG através da técnica de ELISA, utilizando transglutaminase tecidual como antígeno. As dosagens de IgA foram realizadas por turbidimetria.

Resultados: Cinco pacientes com síndrome de Down (7\%) foram positivos para EmA-IgA, com títulos entre $1 / 5$ to $1 / 80$ e catorze $(17,5 \%)$ para anti-tTG (21-340 units). Todos os pacientes positivos para EmA apresentaram simultaneamente positividade para o anti-tTG. Os achados clínicos e histológicos na mucosa intestinal confimaram doença celíaca em quatro pacientes. O outro paciente EmA positivo não foi submetido a biópsia duodenal. Os pacientes positivos apenas para anti-tTG apresentaram valores limítrofes $(<25$ unidades) e eram assintomáticos. Nenhum indivíduo do grupo controle foi positivo para EmA ou anti-tTG. Nenhuma amostra do estudo foi deficiente para IgA.

Conclusões: Os dados do presente estudo mostram alta prevalência $(5,6 \%)$ de doença celíaca confirmada em crianças e adolescentes com síndrome de Down da região sul do Brasil.

J Pediatr (Rio J). 2005;81(5):373-6: Anticorpos anti-endomísio, anticorpos anti-transglutaminase, doença celíaca, síndrome de Down.

\section{Introduction}

Down's syndrome (DS) is the most frequent chromosomal anomaly observed in the general population, affecting 1 in 800 newborns throughout the world and is the main genetic factor for moderate mental retardation. ${ }^{1}$

Different studies have shown that patients with DS present several immune dysfunctions, ${ }^{2,3}$ which lead to increased frequency of recurrent infections, as well as autoimmune diseases. A high association between DS and autoimmune diseases has been already reported by several 
authors, ${ }^{4-6}$ with the most significant association with celiac disease $(C D)^{7-11}$ and autoimmune thyroiditis. ${ }^{12,13}$

$C D$ affects individuals of all ages and is characterized by permanent gluten intolerance. In its classic form, CD appears with symptoms and signs of intestinal malabsorption. However, the disease may occur in a silent or latent form. ${ }^{14}$ According to Marsh, 15 the duodenal mucosa can be normal or present changes ranging from mild alterations to severe atrophy in mucosal architecture. The treatment with a gluten-free diet results in clinical and mucosal recovery, with recurrence of the disease after the return of gluten to the diet. ${ }^{14}$ The classic and symptomatic form of CD is the presence of diarrhea, vomiting and weight loss, which appears in a minority of cases. On the other hand, most of the patients present unspecific gastroenterologic symptoms such as dyspepsia, abdominal pain, flatulence and alteration of the intestinal rhythm. These characteristics often cause delay in $C D$ diagnosis and the incorrect management of patients. ${ }^{14}$

In 1975, Bentley reported for the first time the association between $C D$ and $D S .{ }^{16}$ In the following years, several reports showed increased frequency of $C D$ in individuals with DS in different populations, with a prevalence ranging from 3.2 to $10.3 \% .{ }^{7-11}$ In this study we investigate the prevalence of $C D$ in children with DS from southern Brazil.

\section{Materials and methods}

The institutional ethics committee approved the present investigation.

\section{Patients}

Seventy-one consecutive DS patients ( 32 female and 39 male) with mean age 6.12 years (range 2-18 years) from the DS clinic of the Hospital de Clínicas - Universidade Federal do Paraná (UFPR) (Curitiba, Brazil) were studied. DS patients older than 18 years were excluded from the study. After formal consenting of DS children's first-degree relatives, $3 \mathrm{ml}$ of blood were collected from each subject. Samples were centrifuged and the serum separated, aliquoted and immediately stored at $-80^{\circ} \mathrm{C}$, until used. Only the EmA-IgA/anti-tTG positive patients were clinically evaluated and submitted to upper gastrointestinal endoscopy. Crypt hyperplasia and villous atrophy were classified as partial (PVA) or total (TVA), according to Marsh. ${ }^{15}$

\section{Controls}

Blood samples of 80 healthy children of the same geographic area of the patients, matched with sex and age with the DS group (38 female and 42 male, mean age 8.02 years), range 2-19 years, were used as controls.

\section{EmA-IgA}

All subjects were screened for EmA-IgA according to Volta et al., ${ }^{17}$ using immunofluorescence indirect assay, with human umbilical cord as substrate and FITC anti-IgA human as conjugate (INOVA, USA).

\section{Anti-tTG antibodies}

Anti-tissue transglutaminase IgA antibodies (tTG) were determined by enzyme-linked immunosorbent assay (ELISA) with guinea pig liver tTG as antigen, using a commercial kit (INOVA Diagnostics Inc., San Diego, CA, USA), according to Dieterich et al. ${ }^{18}$ Results were considered positive when higher than 20 units.

\section{Serum IgA}

The total serum IgA levels was determined by turbidimetry (Behring, Germany).

\section{Statistical analysis}

Data were analyzed with Statistica (Microsoft, USA) software, using the Fisher exact test.

\section{Results}

Serological screening for CD based on EmA and tTG antibodies was performed in 71 patients with DS and in 80 healthy children.

These results for DS patients and controls are shown in Figure 1. A highly significant positivity of EmA-IgA ( $p=0.021)$ and anti-tTG $(p<0.001)$ was observed in the DS patients when compared to the controls. Five DS patients $(7 \% ; 5 / 71)$, four male and one female, were positive for EmA-IgA, with titers varying from $1 / 5$ to $1 / 80$. Fourteen patients $(17.5 \% ; 14 / 71)$, seven male and seven female, were positive for anti-tTG antibodies with values from 21 to $340 \mathrm{U} / \mathrm{ml}$. Five of these patients were concomitantly positive for EmA-IgA and the other nine were only positive for anti-tTG antibodies, presenting borderline values (Table 1). None of the 80 control individuals was positive for EmA-IgA or anti-tTG.

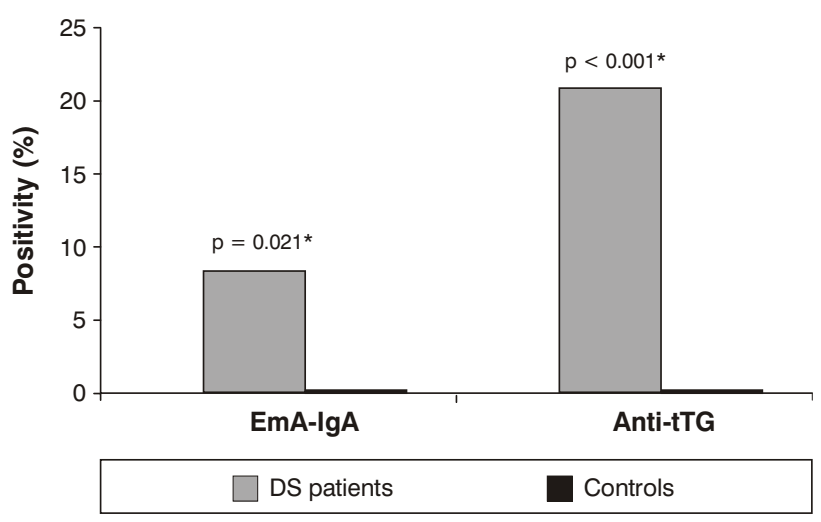

* Fisher exact test

Figure 1 - Anti-endomysial (IgA-EmA) and anti-transglutaminase (tTG) antibodies in Down syndrome patients and controls 
Table 1 - Antiendomisyum and anti-transglutaminase antibodies, symptoms and histologic aspects in DS patients

\begin{tabular}{lllllll}
\hline Patient & Sex & Age & EmA-IgA & $\begin{array}{l}\text { Anti tTG* } \\
\mathbf{( U / m I )}\end{array}$ & Symptoms & $\begin{array}{l}\text { Hystologic } \\
\text { aspects }\end{array}$ \\
\hline C.M. & M & 6 & POS $1 / 5$ & 72 & Symptom-free & ND \\
A.M.E. & M & 8 & POS $1 / 5$ & 30 & Dypepsia, growth failure, abdominal pain & Partial atrophy \\
R.D. & F & 18 & POS $1 / 80$ & 198 & Dyarrheia, abdominal pain & Total atrophy \\
R.K & M & 6 & POS $1 / 80$ & 176 & Dyarrheia, growth failure & Total atrophy \\
R.S.A. & M & 10 & POS $1 / 80$ & 340 & Symptom-free & Total atrophy \\
S.R.O. & F & 4 & Negative & 22 & Symptom-free & ND \\
L.P. & F & 12 & Negative & 21 & Symptom-free & ND \\
R.I. & F & 3 & Negative & 24 & Symptom-free & ND \\
A.O.S. & F & 15 & Negative & 23 & Symptom-free & ND \\
E.H.S. & F & 3 & Negative & 24 & Symptom-free & ND \\
L.I.H. & M & 3 & Negative & 24 & Symptom-free & ND \\
D.M.S. & M & 7 & Negative & 23 & Symptom-free & ND \\
S.R.O. & F & 5 & Negative & 31 & Symptom-free & ND \\
J.B. & M & 4 & Negative & 39 & Symptom-free & ND \\
\hline
\end{tabular}

$\mathrm{ND}=$ Not done. $\quad{ }^{*}$ Reference values: $<20 \mathrm{U} / \mathrm{ml}=$ Negative $; 20$ to $30 \mathrm{U} / \mathrm{ml}=$ weakly positive, $>30 \mathrm{U} / \mathrm{ml}=$ positive.

Among the five patients concomitantly positive for EmAIgA and anti-tTG antibodies, three showed clinical symptoms such as diarrhea, abdominal pain, anemia and growth failure (Table 1). Four of them underwent an upper digestive endoscopy followed by duodenal mucosa biopsy. Histological aspects of duodenal mucosa compatible with $C D$ were observed in all patients, three of them presented TVA and one PVA. Only one asymptomatic patient (EmA 1/5, anti $\mathrm{tTG}=72 \mathrm{UI}$ ) did not undergo digestive endoscopy and duodenal biopsy. Thus, the prevalence of confirmed $C D$ among the investigated DS patients was 5.6\% (4/71).

Neither the DS patients nor the controls presented IgA deficiency.

\section{Discussion}

This is the first report to show the prevalence of CD in children with DS in Brazil. Our findings confirmed the increased prevalence of $C D$ among patients with $D S$ reported by several studies in Europe, North America and Argentina. ${ }^{7-11}$ The prevalence of CD in the general population in these countries ranges from $1: 200$ to $1: 2,000$, and among DS patients it presents a 20-200 fold increase. In Brazil, the prevalence for $C D$ has been estimated to be $0.14 \%(1: 687)$ in the central-western region ${ }^{19}$ and $0.1 \%(1: 1,000)$ in the south region. 20

Although not all EmA positive patients in our study underwent an intestinal biopsy, the confirmed CD prevalence in DS patients was still very high $(5.6 \% ; 1: 18)$, in comparison with the general population of the same geographical area $(1: 1,000)$. If we consider $C D$ prevalence diagnosed by positive $E m A$, this prevalence would be $7 \%$. The high association of CD with DS has not yet been clarified, however both, CD and DS patients present more frequent dysfunction in their immune system and are more predisposed to autoimmune diseases, such as thyroid diseases, diabetes mellitus type 1, lupus and arthritis. 4,5,6,12 Besides that, this association may be related to shared common genetic markers. It has been shown that the DS patients with $C D$ present the characteristic $C D$ associated with high-risk human leukocyte antigens (HLA) DR3 and DQ2 alleles. ${ }^{21}$ In addition, gene disorders caused by chromosomal imbalance may be related to the enhanced expression of $C D$ in $S D$ patients.

Different studies have shown that the most sensitive and specific serologic test for the diagnosis of $C D$ is the assessment of EmA antibodies. During this investigation, five patients were positive for EmA-IgA (7\%) and four of them underwent duodenal biopsy. All patients who underwent intestinal biopsy showed clinical manifestations and histological alterations of intestinal mucosa compatible with $\mathrm{CD}$. The other patient both EmA-IgA and anti tTG positive was asymptomatic and did not undergo biopsy. It is possible that this patient had a latent form of $C D$, which needs to be followed-up. Thus EmA screening showed high sensitivity and specificity for the diagnosis of $C D$ in the investigated patients. Our results corroborate the widely accepted concept that $\mathrm{EmA}-\mathrm{IgA}$ is a specific screening test for $C D$.

EmA negative and anti-tTG positive patients, which did not undergo duodenal biopsy, will now be followed up. Nevertheless, anti-tTG antibodies have been shown to be positive in other diseases such as inflammatory bowel disease, chronic liver disease and diabetes mellitus. ${ }^{22}$ Also, lower specificity of anti-tTG has been related to the use of 
guinea pig liver extract as antigen in the ELISA kit. Recently, the use of human tissue transglutaminase as purified antigen has been shown to enhance the specificity of this assay. 23

In the first 2 years of life, most of the $C D$ patients present classic symptoms and when associated with DS this diagnosis is almost always delayed. Certain characteristics of DS children, such as a distended abdomen and the tendency to consider growth failure as natural consequences of the DS, can be responsible for the difficulty in diagnosing $C D$ in these patients. Thus, several authors consider that the $C D$ is underestimated as the cause of diarrhea, malnutrition or development deficit in patients with DS. 9,24

The importance of the CD investigation in DS patients has been showed in recent studies, which recommended serologic tests every 2 years, since negative young individuals may be positive some years later. ${ }^{9}$

The data reported in the present study emphasize the value of investigating $C D$ in DS patients, since the correct and early diagnosis will offer a better quality of life to the patient and his family.

\section{References}

1. Pueschel SM. Physical characteristics, chromosome analysis and treatment approaches in Down syndrome. In: Tingey C. Down syndrome: a resource handbook. Boston; College-Hill Press/Little, Brown \& Co., 1988. p. 3-21.

2. Avanzini MA, Manafo $V$, De Amici $M$, Maccario R, Burgio GR, Plebani $A$, et al. Humoral immunodeficiency in Down syndrome: serum subclass and antibody response to hepatitis $B$ vaccine. Am J Med Genet. 1990;7:231-3.

3. Nespoli L, Burgio GR, Ugazio AG, Macario R. Immunological features of Down's syndrome: a review. J Intel Disabil Res. 1993;37:543-51.

4. Anwar AJ, Walker JD, Frier BM. Type 1 diabetes and Down's syndrome: prevalence, management and diabetic complications. Diabet Med. 1998;15:160-3.

5. Bakkaloglu A, Besbas SO, Saatci U, Balci S. Down syndrome associated with systemic lupus erythematosus: a mere coincidence or a significant association? Clin Genet. 1994;46: 322-3.

6. Olson JC, Bender JC, Levinson JE, Oestreich A, Lovell DJ. Arthropathy of Down syndrome. Pediatrics. 1990;86:931-6.

7. Bonamico $M$, Mariani $P$, Danesi HM, Crisogianni $M$, Failla $P$, Gemme G, et al. Prevalence and clinical picture of celiac disease in Italian Down syndrome patients: a multicenter study. J Ped Gastroenterol Nutr. 2001;33:139-43.

8. Book L, Hart A, Black J, Feolo M, Zone JJ, Neuhausen SL. Prevalence and clinical characteristics of celiac disease in Down syndrome in a U.S. study. Am J Med Genet. 2001;98:70-4.
9. Csizmadia CG, Mearin ML, Ore $A$, Krombout $A$, Crusius JB, Blomberg ME, et al. Accuracy and cost-effectiveness of a new strategy to screen for celiac disease in children with Down syndrome. J Pediatr. 2000;137:756-60.

10. Kolek A, Vospelová J, Hermanová Z, Santavá A, Tichy M. Occurrence of celiac disease in children with Down's syndrome in north Moravia, Czech Republic. Eur J Pediatr. 2003;162:307-8.

11. Rumbo M, Chirdo FG, Ben R, Saldungaray I, Villalobos R. Evaluation of celiac disease serological markers in Down syndrome patients. Dig Liver Dis. 2002;34:116-21.

12. Rubello D, Pozzan GB, Casara DM, Girelli ME, Boccato S, Rigon F. Natural course of subclinical hypothyroidism in Down syndrome: prospective study results and therapeutic considerations. J Endocrinol Invest. 1995;17:35-40.

13. Shalitin S, Philip M. Autoimmune thyroiditis in infants with Down's syndrome. J Pediatr Endocrinol Metab. 2002;15:649-52.

14. Kotze LM, Barbieri D. Doença celíaca. In: Kotze LM, Barbieri D. Afecções gastrointestinais da criança e do adolescente. $1^{a}$ ed. Rio de Janeiro: Revinter; 2003. p. 189-208.

15. Marsh MN. Mucosal pathology in gluten sensitivity. In: Marsh MN. Coeliac disease. Oxford: Blackwell Scientific Publications; 1992. p. 136-91.

16. Bentley D. A case of Down's syndrome complicated by retinoblastoma and celiac disease. Pediatrics. 1975;56:131-3.

17. Volta U, Molinaro N, De Franceschi L, Fratangelo D, Bianchi FB. IgA anti-endomysial antibodies on human umbilical cord tissue for celiac disease screening. Dig Dis Sci. 1995;40:1902-5.

18. Dieterich W, Laag E, Schopper H. Autoantibodies to tissue transglutaminase as predictors of celiac disease. Gastroenterology. 1998;115:1317-21.

19. Gandolfi L, Pratesi R, Córdoba JC, Tauil PL, Gasparin M, Catasi C. Prevalence of celiac disease among blood donors in Brazil. Am J Gastroenterol. 2000;95:689-92.

20. Nisihara RM, Kotze LM, Mocelin V, Utiyama SR. Serological investigation of celiac disease in southern area from Brazil. Arq Gastroenterol. 2005. In press.

21. Hansson T, Anneren G, Sjoberg O, Klareskog L, Dannaeus A. Celiac disease in relation to immunologic serum markers, trace elements, and HLA-DR and DQ antigens in Swedish children with Down syndrome. J Pediatr Gastroenterol Nutr. 1999;29:286-92.

22. Koop I, Ilchmann R, Izzi L. Detection of autoantibodies against tissue transglutaminase in patients with coeliac disease and dermatitis herpetiformis. Am J Gastroenterol. 2000;95:2009-14.

23. Clemente MG, Musu MP, Frau F, Lucia C, Virgillis S. Antitissue transglutaminase antibodies outside celiac disease. J Ped Gastroenterol Nutr. 2002;34:31-4.

24. Hilhorst MI, Brink M, Wauters EA, Houwen RH. Down syndrome and coeliac disease: five new cases with a review of the literature. Eur J Pediatr. 1993;152:884-7.

\section{Correspondence:}

Renato Mitsunori Nisihara

Laboratório de Imunopatologia

Hospital de Clínicas, Setor de Ciências da Saúde

Rua Padre Camargo, 280

CEP 80060-240 - Curitiba, PR

E-mail: renatomitsu@yahoo.com.br 